\title{
Adaptation and psychometric analysis of the Emotional Intelligence View Nowack's (EIV) questionnaire in the Portuguese context
}

\author{
Adelinda Araújo Candeias ${ }^{1,2}$, Edgar Galindo², \& Ana Rocha ${ }^{3}$ \\ ${ }^{1}$ Escola de Saúde e Desenvolvimento Human, Universidade de Évora \\ ${ }^{2}$ Comprehensive Health Research Cente, Universidade de Évora \\ ${ }^{3}$ Universidade Católica de Angola, Luanda, Angola
}

\begin{abstract}
During the last two decades, several studies have demonstrated the usefulness of emotional intelligence (EI) to understand job performance, job satisfaction, and well-being and quality of life (Nowack, 2006, 2014). This study analyzes the psychometric properties of the Emotional Intelligence View (EIV) in the Portuguese population. Participants were 708 professionals working in different job sectors (banking, management, and health) from the whole country. The EIV is a self-report scale composed of 74 items assessing emotional intelligence in organizations. It is organized in five dimensions: General EI competence, self-management, adaptability, relationship management, and leadership. The results showed that EIV presents a coherent factor structure. Results pointed to differences between men and women concerning leadership and emotional self-management. Positive correlations were found between age and educational level. It is concluded that EIV is a valid and reliable measure to evaluate EI in professionals working in different job sectors.
\end{abstract}

Keywords: Emotional Intelligence; Emotional Intelligence View (EIV); Psychometric Properties; Workplace.

Adaptação e Análise da Estrutura Psicométrica da Escala de Inteligência Emocional de Nowack (EIV) para o Contexto Português: Nas últimas duas décadas, vários estudos mostraram a utilidade da inteligência emocional (EI) para compreender o desempenho e a satisfação profissional, o bem-estar e a qualidade de vida (Nowack, 2014). 0 objetivo deste estudo é analisar as propriedades psicométricas do Questionário de Inteligência Emocional (EIV) na população portuguesa. Participaram 708 profissionais de todo o país. O EIV é uma escala de autorrelato composta por 74 itens, que avalia a inteligência emocional em contexto organizacional, está estruturado em cinco dimensões: competência geral de IE, autogestão, adaptabilidade, gestão de relações e liderança. Os resultados encontrados mostraram que o EIV apresenta uma estrutura fatorial semelhante à composição original americana (Nowack, 2004, 2014). Foram encontradas diferenças favoráveis aos homens nos fatores de liderança e autogestão emocional e correlações positivas com a idade e o nível educacional. Conclui-se que o EIV é uma medida válida para avaliar a IE em profissionais de diferentes áreas.

Palavras-chave: Inteligência emocional; Questionário de Inteligência Emocional (EIV); Propriedades psicométricas; Local de trabalho.

In today's organizational world, companies are challenged to increasingly shorten their reaction times, while competitive pressure is constantly increasing. This heightens the importance of emotional intelligence (EI) as a key strategy for achieving organizational goals (Ackley, 2016). This is because individuals' emotions and perception, regulation, and communication influence the success or failure of the entity's performance, while also contributing to the quality of work relationships and reflecting on the company's productivity (Gunkel et al., 2016; Moreira, 2017). EI has also proved to be a valuable tool in people management, identifying, for example, what factors lead employees to engage in a given task, or even how they might be encouraged to adopt more positive attitudes in the organizational environment or to tackle challenges (Maamari \& Majdalani, 2017; Nowack, 2004).

The EI concept appeared as a psychological construct in 1990 (Salovey \& Mayer, 1990), representing individuals' ability to monitor and discriminate their feelings and emotions and those of others to guide thought and actions. It is defined as an ability to perceive and process emotional information for better results (Mayer \& Salovey, 1997). In an eclectic approach, Goleman (1995) defined EI as the competence to

${ }^{1}$ Correspondence address: Adelina Araújo Candeias, Morada de correspondência: Universidade de Évora, Colegio Pedro da Fonseca, Ap. 94, 7002-554 Évora. E-mail: aac@uevora.pt 
manage emotions, which are assumed to be important not only in aiding staff to understand themselves better and better guide their thinking and behavior but also to improve their relationships with others. This EI description was later redefined as people's ability to identify effectively, understand, use, and manage their own and others' emotional states. Goleman (1998) stressed that people could use emotions to motivate themselves, better manage their own emotions, and better interact with others (Njoroge \& Yazdanifard, 2014). In particular, EI became recognized as an important variable when Goleman (1998) emphasized its role in organizations. Since then, it has become the subject of numerous studies looking at its correlations with a wide range of variables within the work context. Other studies have suggested that EI is critical for achieving workplace equilibrium (Goleman, 2012; Maamari \& Majdalani, 2017). Its role in career success and job performance has been shown to surpass general intelligence or cognitive ability (Nowack, 2004, 2006). Nowack (2006) proposed that self-awareness or self-insight is an essential aspect of any definition of EI. This concept deals with a type of intrapersonal intelligence often described as the ability to understand oneself and use that information to regulate one's own life (Goleman, 1998). Research suggests that individuals who lack self-awareness might not accurately see the impact of their behavior on others, misjudge how others experience their behavior, and lack the capacity to capitalize on others' feedback. In this context, Nowack (2004) developed the EI View360 (EIV) based on Goleman's 1998 concept of EI measuring 22 competencies in four critical areas including: 1) self-awareness; 2) social awareness; 3) self-management; and 4) relationship management. Comparing one's own and others' perceptions on a 360-feedback tool serves both understanding and self-awareness. The perceptual gap between self and others' perceptions helps to regulate self-awareness. Based on these assumptions, the EIV panoramic tool brings together a set of critical interpersonal, social, and communication competencies in three specific theoretical areas: 1) self-management, 2) relationship management; and 3) communication. Previous studies yielded the 2004 copyrighted, 74-item version organized into 17 critical competencies. The use of multi-rater $360^{\circ}$ or panoramic assessment inventory (thus named since feedback is collected from many people surrounding the respondents and includes the perceptions of workers' managers, peers, and/or customers) has become commonplace and productive in organizations because, by comparing one's perception with those of others, the tool provides a panoramic perspective of the social and emotional competences of employees and leaders.

From its beginning, this tool has been studied for several purposes, including coaching, management development, supervisory training, employee development programs, career development, and other organizational contexts. Nowack (2004), for example, with an American sample (N=734), used principal component factoring with iteration and varimax rotation to identify five unique factors with eigenvalues greater than 1.0 that accounted for $71 \%$ of the variance: General competence of IE, Self-management, Adaptability, Relationship management, and Leadership. Instrument reliability ranged from .67 to .89.

The past two decades have witnessed various tools, including EIV, proving the EI construct's usefulness for understanding job performance, leadership, job satisfaction, well-being, and quality of life (Nowack, 2006, 2014). An association with job performance has also been revealed (e.g., Barbosa \& Carvalho de Sousa, 2016; Davar \& Singh, 2014; Joseph et al., 2015; Lee \& Chelladurai, 2017). A metaanalysis ( $\mathrm{N}=4151$ ) (Miao et al., 2017) showed that EI is positively related to job resources, which, in turn, mediates the relationship between EI and job satisfaction. Moreover, the relationship between EI and job satisfaction does not differ across sex, age, or tenure. Thus, regardless of whether an employee is male or female, young or old, a recent or long-term hire, they benefit equally from EI. This happens when staff members seek job resources. Another finding is that job resources and EI are mutually reinforcing, bringing practical advantages to employee job satisfaction. The interaction between EI and well-being and quality of life has also been explored. Min (2013) found that EI was positively associated with quality of life (QOL), while a negative link was identified between occupational stress and QOL. The results suggested practical interventions for enhancing tour guides' competencies of EI and stress management, resulting in higher levels of QOL. Nowack (2017) revealed that leaders who reported low quality and quantity of sleep received lower interpersonal effectiveness ratings from direct reports and peers. These results support others pointing to a positive relationship between higher EI levels and good communication and conflict resolution, especially for managers. Thus, workplace leaders and supervisors using emotionally intelligent behavior may significantly influence worker performance (e.g., Gunkel et al., 2016; Webb, 2014). Therefore, EI is crucial to leaders' work efficiency. Those who have achieved a certain level of EI are better aware of their teams' needs and can provide staff with regular effective feedback that enables them to improve their organizational performance (Njoroge \& Yazdanifard, 2014).

In sum, recent research points explicitly to the importance of an eclectic approach seeing EI as a set of critical interpersonal, social, and communication competencies for dealing with others and aiding staff members to understand themselves better. To improve thinking and behavior, reliable and valid tools for assessing EI must be made available. Portuguese research has some limitations in this regard (see Candeias 
\& Canhoto, 2019), namely, small samples collected within limited population types. Moreover, much of the data available comes from $360^{\circ}$ panoramic evaluations, which, while beneficial in workplace practice, fail to guarantee anonymity due to the need to cross-check data from employees and managers. This fact leads to the risk of inducing employee bias.

This study is intended to enlarge previous ones by gathering more heterogeneous samples of Portuguese businesspeople. It uses self-rating scales to increase the reliability, validity, and generalizability of the EIV construct.

\section{METHOD}

\section{Participants}

Participants were 708 Portuguese employees from three different sectors: banking $(N=386,54.5 \%)$, management $(N=160,22.9 \%)$, and health $(N=162,22.6 \%)$, from across the country, $349(49.3 \%)$ males and 359 females (50.7\%). The men's ages ranged from 22 to $57(M=38.31 ; S D=8.81) .176(51.2 \%)$ had completed secondary level education, while 116 (33.8\%) had a university degree or higher. The women ranged from 18 to $58(M=34.54 ; S D=7.79)$ in age; $103(29.0 \%)$ had completed secondary school, and 200 $(6.4 \%)$ had a university degree.

\section{Instrument}

The emotional Intelligence View 360 (EIV) - Portuguese version - Self-rating version (EIV). The EIV is a questionnaire developed by Nowack (2004) (with commercial versions in 2006 and 2014). It consists of three competency groups (self-management, relationship management, communication), 17 competencies, and 74 items/questions in total. The tool assesses perceptions of emotional competence to support the evaluation and development of those skills in workers.

The instrument was translated and adapted to Portuguese at the University of Evora under the coordination of A. A. Candeias with author authorization from Nowack (University of California, USA) and Podsakoff (University of Indiana, USA) (for more details, see Rocha et al., 2007). The contents were adapted to the Portuguese linguistic and cultural context to preserve semantic equivalence by ITC Guidelines (Bartram \& Hambleton, 2016; Bartram et al., 2018).

Just as in the case of the original tool, the Portuguese version EIV is organized in previous 17 scales composing the following three main theoretical dimensions, proposed by Nowack in 2014:

\section{Self-Management Competencies}

1. Self-development refers to managing one's own time effectively, energy, and abilities for continuous personal growth and maximum performance - e.g., Manages time effectively and efficiently Adaptability/Stress. Items: 1, 18, 35, 52.

2. Tolerance deals with workers' ability to maintain balance and perform under pressure and stress, e.g., Handles pressure and stress well (e.g., maintains poise, stays calm under pressure, avoids losing control of his/her emotions or behavior). Items: 2, 19, 36, 53, 65.

3. Self-control focuses on people's ability to manage and control their emotions and behavior in the face of interpersonal conflict - e.g., Handles tense situations without overreacting, becoming overly emotional, or defensive. Items: 3, 20, 37, 54, 66.

4. Trustworthiness assesses the degree to which participants demonstrate and practice high standards of personal and professional integrity to create trusting relationships with others - e.g., Maintains openness, honesty, and openness in interpersonal relationships. Items: 4, 21, 38, 55.

5. Strategic problem-solving looks at people's ability to analyze a situation, identify alternative solutions, and carry out specific actions - e.g., Makes decisions confidently and quickly when necessary. Items: $5,22,39,56,67$.

6. Achievement orientation studies the ability to accomplish tasks, projects, and assignments on time and with quality - e.g., Demonstrates the ability to complete tasks, projects, and assignments on time and with quality. Items: 6, 23, 40, 57.

\section{Relationship Management Competencies}

1. Building strategic relationships refers to subjects' ability to initiate and cultivate strategic internal and external networking relationships that foster both individual and organizational goals, e.g., Develops, cultivates, and maintains a broad base of support among key internal and external stakeholders (e.g., managers, employees, customers). Items: 7, 24, 41. 
2. Conflict management looks at people's capacity to negotiate and effectively resolve interpersonal differences with others, e.g., Allow for disagreements to emerge and be discussed openly. Items: 8, 25, 42, 58, 68.

3. Leadership/Influence studies the ability to utilize appropriate interpersonal styles and approaches for guiding groups towards achieving tasks, e.g., Demonstrates a willingness to assert his/her ideas and opinions in the face of opposition and interpersonal challenge. Items: 9, 26, 43, 59, 69.

4. Sensitivity/Empathy assesses people's ability to act in ways that demonstrate consideration for others' feelings and needs, e.g., Shows an interest in and is considerate of others' feelings and needs. Items: $10,27,44,60,70$.

5. Team/Interpersonal support focuses on the degree to which a person assists, motivates, encourages, and supports those who depend on each other to accomplish tasks, projects, and assignments, e.g., Acknowledges and recognizing the contributions accomplishments of others. Items: 11, 28, 45, 61, 71.

6. Collaboration deals with people's tendency to establish and develop cooperative, supportive and collaborative working relationships with others - e.g., Works collaboratively and non-competitively with others. Items: $12,29,46,62,72,73$.

\section{Communication}

1. Written communication focuses on workers' ability to express written thoughts and ideas clearly and concisely, e.g., Writes in a logical, organized, clear, and persuasive manner. Items: 13, 30, 47.

2. Two-way feedback looks at the capacity to keep others informed in a timely manner, e.g., Communicates information needed by others in a prompt and timely manner. Items: 14, 31, 48.

3. Oral communication gauges people's ability to convey oral thoughts and ideas clearly and concisely, e.g., Provides clear, succinct, and logical answers to questions from others. Items: 15, 32, 49, 74.

4. Oral presentation studies the capacity to present individual and organizational viewpoints to groups clearly and persuasively, e.g., Restates and clarifies important points and questions from others during presentations. Items: 16, 33, 50, 74.

5. Listening assesses subjects' ability to pay attention to and understand others' verbal communications, e.g., Waits out silences and listens patiently without interrupting others. Items: 17, 34, 51, 64 .

The adapted version of the EIV questionnaire has been validated in several studies and various workplaces for Portuguese professionals (e.g., Boazinha, 2014; Candeias \& Canhoto, 2019; Candeias \& Jesus, 2006; Rocha et al., 2007; Saraiva, 2007). These studies revealed five main factorial dimensions derived from the previous theoretical organization, similar to the former factorial structure presented by Nowack (2004), that identified a main general factor of emotional intelligence competence and more four factors (self-management, adaptability, leadership, and relationship management with very good values for Cronbach alpha of .982 (Rocha et al., 2007) and .986 (Boazinha, 2014).

Each item was measured using a five-point Likert scale ranging from strongly agree (five-point) to strongly disagree (one point).

An electronic questionnaire was prepared according to the guidelines proposed by Eysenbach (2012). The tool's usability and functionality were pre-tested using Limesurvey (version 2.05) with a group of students from the master's degree in psychology $(\mathrm{N}=20)$.

\section{Procedure}

This study is part of a larger project entitled: "Wellbeing in the Workplace" (WBW). Firstly, we gained authorization to carry out the study from the Portuguese Commission for Data Protection, the Ethical and Scientific Committee for Monitoring Research of the University of Évora, and all participating institutions' directors. The questionnaire was disseminated via email and social networks to several banking, health, and services organizations during 2016 and 2017. The instrument's introduction presented the project and outlined all ethical, confidentiality, and anonymity protections to safeguard data. Participants filled out an informed consent form. In return for their participation, respondents were invited to request copies of the research results distributed by late 2018. Each of the questionnaires received by the Limesurvey platform was checked, downloaded, and transformed into an SPSS Statistics data file. Data analysis was carried out using Statistical Package for Social Sciences (SPSS) version 20.0 for Windows 


\section{RESULTS}

This study is part of a larger project entitled: "Wellbeing in the Workplace" (WBW). Firstly, we gained authorization to carry out the study from the Portuguese Commission for Data Protection, the Ethical and Scientific Committee for Monitoring Research of the University of Évora, and all participating institutions' directors. The questionnaire was disseminated via email and social networks to several banking, health, and services organizations during 2016 and 2017. The instrument's introduction presented the project and outlined all ethical, confidentiality, and anonymity protections to safeguard data. Participants filled out an informed consent form. In return for their participation, respondents were invited to request copies of the research results distributed by late 2018. Each of the questionnaires received by the Limesurvey platform was checked, downloaded, and transformed into an SPSS Statistics data file. Data analysis was carried out using Statistical Package for Social Sciences (SPSS) version 20.0 for Windows. Descriptive analyses are shown in Table 1.

\section{Validity}

Content validity assessed the degree to which the test content (items) covered the most important aspects of Nowack's construct of emotional intelligence and its dimensions $(2004,2014)$. A factor analysis (FA) using principal component extraction (PCA) with iteration and varimax rotation looked at the EIV factorial structure (Fabrigar \& Wegener, 2012), namely:

1. The goal was to create variables (components) that maximized interindividual variance-that is, try to create an index where people differed most because, as Nowack states, the general index of EI is an outcome of the indicators.

2. Components were always orthogonal, i.e., each component explained non-redundant information.

3. Components were linear combinations of indicators: items (xx) predicted components (zz): $\mathrm{x} \rightarrow \mathrm{zX} \rightarrow \mathrm{Z}$.

4. Our goal was to explain variable variances, with components accounting for maximal variance in observed variables.

PCA was carried out with interaction and varimax rotation of the factors to obtain a clearer and more objective factorial solution (Brown, 2006). Six fundamental steps guided the data analysis as suggested by Kaiser-Meyer-Olkin (KMO): (a) factors with a value equal to or greater than 1 were retained; (b) items with eigenvalues equal to or greater than 0.35 were kept; (c) factors retained had to explain at least $40 \%$ of the variance; (d) the reliability factor had to be equal to or greater than 0.70 (Anastasi \& Urbina, 2000); and (e) the factors had to be understandable or interpretable within the scope of the theory.

We began with an exploratory analysis based on eigenvalues higher than 1 and found an 8-factor solution explaining $63.12 \%$ of variance. The last 3 factors had 4 or fewer items, so it was decided to analyze PCA for 5 factors, as done in the original study (Nowack, 2004). The sample adequacy measure (KMO test $=0.98$ ) indicated that the analysis of the main components could be performed, and the sphericity test significance $(35250.91 ; p<0.001)$ revealed that the items were interdependent. Table 2 presents the loadings by item and factor with loadings ranging from 0.383 to 0.775 . Thus, a solution of five factors resulted in explaining $58.34 \%$ of total variance (see Table 3 ).

1. The largest factor accounted for over $46.16 \%$ of the variance. It included all 51 items, which suggests a mega factor might be considered a global index of self and relationship management (Global EIV factor), as Nowack originally proposed (2006).

2. The second factor accounted for $4.23 \%$ of the variance. It included 17 items dealing with communication: written communication, two-way feedback, oral communication and oral presentation, tolerance, and self-control (Communication and relationship management).

3. The third factor accounted for $3.13 \%$ of the variance and included 13 items focusing on strategic relationship, adaptability, conflict resolution, and leadership (Leadership).

4. The fourth factor accounted for $2.79 \%$ of the variance and took in 7 items focusing on self-control and tolerance (Self-management).

5. The fifth factor accounted for $2.03 \%$ of the variance and included 6 items looking at conflict management, trustworthiness, relationship management, strategic problem solving, and achievement orientation (Stress management/Adaptability). 
Table 1: Descriptive analysis of the items of EIV ( $\mathrm{N}=708)$

\begin{tabular}{|c|c|c|c|c|c|c|c|c|c|c|c|}
\hline Items & $\mathbf{M}$ & SD & Min & Max & Ritc & Items & $\mathbf{M}$ & SD & Min & Max & Ritc \\
\hline 1 & 3.91 & .831 & 1 & 5 & .672 & 38 & 4.16 & .839 & 1 & 5 & .766 \\
\hline 2 & 3.95 & .834 & 1 & 5 & .650 & 39 & 4.19 & .723 & 1 & 5 & .704 \\
\hline 3 & 3.69 & .926 & 1 & 5 & .555 & 40 & 4.42 & .726 & 1 & 5 & 689 \\
\hline 4 & 4.29 & .793 & 1 & 5 & .697 & 41 & 3.99 & .845 & 1 & 5 & .634 \\
\hline 5 & 4.10 & .769 & 1 & 5 & .638 & 42 & 3.73 & .902 & 1 & 5 & .600 \\
\hline 6 & 4.34 & .789 & 1 & 5 & .586 & 43 & 3.63 & .849 & 1 & 5 & .416 \\
\hline 7 & 3.66 & .913 & 1 & 5 & .463 & 44 & 4.20 & .849 & 1 & 5 & 699 \\
\hline 8 & 3.84 & .983 & 1 & 5 & .627 & 45 & 4.30 & .815 & 1 & 5 & .770 \\
\hline 9 & 3.66 & .965 & 1 & 5 & .416 & 46 & 4.05 & .820 & 1 & 5 & .712 \\
\hline 10 & 3.87 & .885 & 1 & 5 & .687 & 47 & 4.12 & .815 & 1 & 5 & .616 \\
\hline 11 & 3.91 & .924 & 1 & 5 & .712 & 48 & 4.17 & .797 & 1 & 5 & .755 \\
\hline 12 & 4.01 & .879 & 1 & 5 & .744 & 49 & 4.18 & 699 & 1 & 5 & .724 \\
\hline 13 & 4.05 & .760 & 1 & 5 & .561 & 50 & 4.10 & .792 & 1 & 5 & .712 \\
\hline 14 & 4.13 & .830 & 1 & 5 & .747 & 51 & 4.17 & .810 & 1 & 5 & .756 \\
\hline 15 & 4.43 & .725 & 1 & 5 & .655 & 52 & 3.95 & .817 & 1 & 5 & .565 \\
\hline 16 & 3.88 & .887 & 1 & 5 & .639 & 53 & 4.00 & .914 & 0 & 5 & .476 \\
\hline 17 & 3.60 & .913 & 1 & 5 & .545 & 54 & 4.18 & .733 & 1 & 5 & .575 \\
\hline 18 & 4.19 & .799 & 1 & 5 & .697 & 55 & 4.31 & .752 & 1 & 5 & .710 \\
\hline 19 & 3.88 & .850 & 1 & 5 & .715 & 56 & 4.10 & .712 & 1 & 5 & .573 \\
\hline 20 & 3.57 & 1.020 & 1 & 5 & .532 & 57 & 4.48 & .679 & 1 & 5 & .739 \\
\hline 21 & 4.33 & .813 & 1 & 5 & .753 & 58 & 4.12 & .834 & 1 & 5 & .711 \\
\hline 22 & 4.25 & .734 & 1 & 5 & .678 & 59 & 4.03 & .775 & 1 & 5 & .744 \\
\hline 23 & 4.26 & .768 & 1 & 5 & .670 & 60 & 4.30 & .841 & 1 & 5 & .760 \\
\hline 24 & 3.89 & .875 & 1 & 5 & .595 & 61 & 4.33 & .760 & 1 & 5 & .767 \\
\hline 25 & 3.71 & .888 & 1 & 5 & .656 & 62 & 4.38 & .757 & 1 & 5 & 685 \\
\hline 26 & 3.22 & 1.073 & 1 & 5 & .385 & 63 & 4.02 & .776 & 1 & 5 & .678 \\
\hline 27 & 4.30 & .890 & 1 & 5 & .604 & 64 & 4.00 & .855 & 1 & 5 & .625 \\
\hline 28 & 3.88 & .881 & 1 & 5 & .734 & 65 & 3.97 & .806 & 1 & 5 & .730 \\
\hline 29 & 4.21 & .838 & 1 & 5 & .680 & 66 & 3.79 & .847 & 1 & 5 & .578 \\
\hline 30 & 4.12 & .779 & 1 & 5 & .580 & 67 & 4.03 & .742 & 1 & 5 & .752 \\
\hline 31 & 4.12 & .825 & 1 & 5 & .734 & 68 & 3.80 & .819 & 1 & 5 & .711 \\
\hline 32 & 4.21 & .746 & 1 & 5 & .679 & 69 & 3.98 & .737 & 1 & 5 & .597 \\
\hline 33 & 4.13 & .846 & 1 & 5 & .563 & 70 & 4.22 & .859 & 1 & 5 & .782 \\
\hline 34 & 4.46 & .705 & 1 & 5 & .695 & 71 & 4.15 & .816 & 1 & 5 & .745 \\
\hline 35 & 4.01 & .824 & 1 & 5 & .749 & 72 & 4.32 & .809 & 1 & 5 & .774 \\
\hline 36 & 3.86 & .927 & 1 & 5 & .649 & 73 & 4.19 & .824 & 1 & 5 & .808 \\
\hline 37 & 3.85 & .903 & 1 & 5 & .645 & 74 & 4.12 & .740 & 1 & 5 & .744 \\
\hline
\end{tabular}


Table 2. Principal component analysis in EIV (Convergence for10 interactions) (N=708)

\begin{tabular}{|c|c|c|c|c|c|c|c|c|c|c|c|}
\hline \multirow[b]{2}{*}{ Item } & \multicolumn{5}{|c|}{ Component } & \multirow{2}{*}{$\begin{array}{l}\text { Item } \\
\text { (Cont.) }\end{array}$} & \multicolumn{5}{|c|}{ Component (cont.) } \\
\hline & 1 & 2 & 3 & 4 & 5 & & $\begin{array}{c}1 \\
\text { (Cont.) }\end{array}$ & $\begin{array}{c}2 \\
\text { (Cont.) }\end{array}$ & $\begin{array}{c}3 \\
\text { (Cont.) }\end{array}$ & $\begin{array}{c}4 \\
\text { (Cont.) }\end{array}$ & $\begin{array}{c}5 \\
\text { (Cont.) }\end{array}$ \\
\hline ie70 & .775 & .234 & .253 & .184 & .085 & ie13 & .138 & .610 & .240 & .092 & .232 \\
\hline ie73 & .773 & .264 & .229 & .174 & .171 & ie33 & .122 & .608 & .269 & .136 & .190 \\
\hline ie72 & .761 & .237 & .160 & .181 & .213 & ie74 & .451 & .570 & .220 & .166 & .189 \\
\hline ie60 & .760 & .192 & .228 & .188 & .140 & ie63 & .350 & .550 & .363 & .131 & .059 \\
\hline ie 45 & .748 & .227 & .217 & .142 & .214 & ie 48 & .517 & .533 & .225 & .077 & .240 \\
\hline ie71 & .725 & .209 & .282 & .143 & .117 & ie 16 & .134 & .507 & .468 & .186 & .245 \\
\hline ie62 & 697 & .233 & .070 & .192 & .169 & ie 54 & .357 & .480 & .057 & .266 & .057 \\
\hline ie 44 & .685 & .121 & .258 & .195 & .157 & ie17 & .090 & .478 & .475 & .124 & .126 \\
\hline ie51 & .663 & .259 & .255 & .281 & .074 & ie31 & .469 & .476 & .196 & .229 & .215 \\
\hline ie21 & .659 & .231 & 139 & .279 & .280 & ie50 & .396 & .471 & .289 & .367 & .010 \\
\hline ie61 & .653 & .320 & .279 & .150 & .160 & ie67 & .347 & .467 & .294 & .367 & .248 \\
\hline ie58 & .637 & .178 & .317 & .252 & .060 & ie52 & .337 & .445 & .006 & .238 & .227 \\
\hline ie46 & .615 & .268 & .363 & .112 & .072 & ie56 & .348 & .440 & .136 & .203 & .109 \\
\hline ie 40 & .607 & .337 & .019 & .122 & .362 & ie 9 & .046 & .193 & .672 & -.017 & .135 \\
\hline ie29 & .599 & .215 & .047 & .311 & .274 & ie8 & .405 & .089 & .623 & .080 & .198 \\
\hline ie57 & .588 & .418 & .044 & .177 & .338 & ie26 & .168 & .057 & .596 & .153 & -.115 \\
\hline ie38 & .581 & .325 & .102 & .322 & .339 & ie 43 & .070 & .282 & .592 & .037 & -.016 \\
\hline ie55 & .580 & .298 & .192 & .269 & .143 & ie 25 & .337 & .181 & .552 & .287 & .139 \\
\hline ie12 & .553 & .135 & .436 & .205 & .308 & ie7 & .089 & .185 & .541 & .068 & .297 \\
\hline ie28 & .541 & .315 & .368 & .183 & .132 & ie 10 & .453 & .074 & .503 & .239 & .291 \\
\hline ie14 & .519 & .331 & .270 & .151 & .374 & ie69 & .206 & .340 & .503 & .167 & .190 \\
\hline ie27 & .511 & .114 & .197 & .316 & .149 & ie42 & .393 & .190 & .486 & .200 & .015 \\
\hline ie39 & .494 & .315 & .185 & .252 & .300 & ie 24 & .205 & .333 & .472 & .168 & .234 \\
\hline ie34 & .484 & .453 & .128 & .216 & .198 & ie41 & .279 & .358 & .418 & .208 & .192 \\
\hline ie59 & .480 & .383 & .432 & .200 & .082 & ie37 & .267 & .216 & .157 & .782 & .146 \\
\hline ie65 & .474 & .298 & .317 & .434 & .059 & ie36 & .290 & .173 & .117 & .775 & .237 \\
\hline ie1 & .469 & .111 & .401 & .257 & .265 & ie 20 & .195 & .089 & .188 & .716 & .157 \\
\hline ie53 & .458 & .237 & -.050 & .288 & .016 & ie3 & .211 & .149 & .157 & .657 & .216 \\
\hline ie35 & .453 & .389 & .330 & .232 & .253 & ie66 & .366 & .283 & .113 & .587 & -.096 \\
\hline ie11 & .448 & .164 & .410 & .235 & .379 & ie68 & .499 & .205 & .254 & .525 & .067 \\
\hline ie15 & .439 & .392 & .121 & .171 & .323 & ie64 & .451 & .338 & .121 & .472 & -.074 \\
\hline ie19 & .426 & .185 & .319 & .351 & .383 & ie23 & .263 & .479 & .146 & .159 & .587 \\
\hline ie2 & .383 & .130 & .344 & .355 & .309 & ie6 & .269 & .299 & .220 & .093 & .561 \\
\hline ie47 & .180 & .700 & .268 & .122 & .115 & ie 5 & .227 & .342 & .342 & .149 & .518 \\
\hline ie 49 & .416 & .692 & .217 & .071 & .123 & ie18 & .456 & .297 & .206 & .126 & .510 \\
\hline ie30 & .193 & .666 & .156 & .154 & .134 & ie 22 & .372 & .379 & .133 & .203 & .503 \\
\hline ie32 & .304 & .627 & .254 & .134 & .184 & ie 4 & .423 & .310 & .158 & .276 & .443 \\
\hline
\end{tabular}

Table 3: Principal component analysis - Total variance explained

\begin{tabular}{llll}
\hline Component & Total & \% of Variance & Cumulative \% \\
\hline 1 & 34.16 & 46.16 & 46.16 \\
2 & 3.13 & 4.23 & 50.39 \\
3 & 2.31 & 3.13 & 53.55 \\
4 & 2.06 & 2.79 & 56.31 \\
5 & 1.50 & 2.03 & 58.34 \\
\hline
\end{tabular}




\section{Reliability Analysis}

Internal consistency reliability (Cronbach's $\alpha$ ) was calculated for each factor or scale, and moderately high coefficients ranged from .98 to.86 (Table 4).

Table 4: Reliability analysis - Cronbach's Alpha ( $\mathrm{N}=708)$.

\begin{tabular}{lll}
\hline Component & $\mathbf{N}$ & Cronbach's $\boldsymbol{\alpha}$ \\
\hline 1 & 708 & .98 \\
2 & 708 & .94 \\
3 & 708 & .87 \\
4 & 708 & .89 \\
5 & 708 & .86 \\
\hline
\end{tabular}

\section{Differential analysis}

First, we looked at the correlation between EIV and personal and social variables, namely, age and level of education, and then we analyzed sex differences in EIV. Significant positive correlations appeared between global EIV and age, while negative ones arose between leadership and age. This suggests that older people have higher self-perceptions of EI but lower self-perceptions of leadership. The results also showed that global EIV decreases with higher education, while self-perception of leadership competencies grows (Table 5).

Table 5: Analysis of correlation between EIV and personal and social variables (N=694)

\begin{tabular}{lll}
\hline Variable & Age & Level of Education \\
\hline EIV Global & $.145^{* *}$ & $-.204^{* *}$ \\
Communication & .004 & .061 \\
Leadership & $-.098^{*}$ & $.096^{*}$ \\
Self-management & -.070 & -.044 \\
Adaptability & -.049 & .059 \\
\hline
\end{tabular}

*. Correlation is significant at the 0.05 level (2-tailed).

**. Correlation is significant at the 0.01 level (2-tailed).

Finally, the analysis of sex differences (Table 6) across the five EIV scales revealed significant differences. Men's self-ratings were significantly higher than women's both for leadership $(\mathrm{N}=615$; $F(1,613)=6.76, p<.01)$ and self-management $(\mathrm{N}=615 ; F(1,613)=21.17, p<.001)$.

Table 6: Sex differences ( $\mathrm{N}=615)$

\begin{tabular}{lllllll}
\hline Dimensions of EIV & Sex & N & Mean & Std. Deviation & F & Sig. \\
\hline \multirow{2}{*}{ EIV Global EIV } & Men & 305 & 0.03 & 0.85 & .63 & .429 \\
& Women & 310 & -0.03 & 1.13 & 2.96 & .086 \\
Communication & Men & 305 & 0.07 & 0.94 & & \\
& Women & 310 & -0.07 & 1.05 & 6.76 & .010 \\
Leadership & Men & 305 & 0.11 & 0.96 & & .000 \\
\multirow{2}{*}{ Self-management } & Women & 310 & -0.10 & 1.03 & & .17 \\
& Men & 305 & 0.18 & 0.92 & .41 & .522 \\
\hline \multirow{2}{*}{ Adaptability } & Women & 310 & -0.18 & 1.04 & & \\
\hline
\end{tabular}

\section{DISCUSSION}

This study's main purpose was to analyze the psychometric properties of the EIV in the Portuguese population, using a large and heterogeneous sample of Portuguese professionals working in the banking, management, and health sectors. The results showed that the factor structure and the composition of the EIV reflect Nowack's five factors $(2004,2014)$ and suggested that the instrument is a valid and reliable measure (Kline, 2010). The five main dimensions formerly pointed out by Nowack $(2004,2014)$ were also 
identified in the Portuguese version: general competence of EI, self-management, adaptability, relationship management, and leadership.

Correlational studies revealed a positive relationship between age, educational level, and EIV, as shown in previous studies (e.g., Nowack, 2004). On the other hand, differences were found between men and women in leadership and emotional self-management, with results more positive for men. Gender differences have also been found in American studies, in which women showed higher competence in empathy and communication (Nowack, 2014). The current results point to the necessity of more research in the field. Future normative studies should analyze differences among gender, age groups, and educational levels in the Portuguese population.

The current results show that the EIV is a valid and reliable tool for a better understanding of the emotional competencies of self-management, relationship management, and communication in the workplace. These results, together with previous Portuguese investigations (e.g., Boazinha, 2014; Candeias \& Canhoto, 2019, Candeias \& Jesus, 2006; Nowack, 2017, Rocha et al., 2007,) show the significant theoretical, empirical and practical value of EIV for coaching, management development, supervisory training, employee development programs, career development, programs for improving professionals' quality of life and well-being.

In the current study, a non-probabilistic sampling procedure was used, in which most participants were adult volunteers. Further investigation should focus on the generalizability of EI factors. On the other hand, both phases of the present study made exclusive use of quantitative methods. Future research might profitably combine other methods (e.g., interview) and compare the EIV with other instruments (e.g., BarOn's EQ-I, 1997) to assess the concurrent validity of the EIV results, as well as the possible relationships with other constructs, such as stress and burnout, well-being, quality of sleep, job commitment and performance (e.g., Gunkel et al., 2016; Lee \& Chelladurai, 2017; Nowack 2017).

Finally, it could be pertinent to carry out longitudinal studies to analyze the effects of development and professional experience on such competencies' stability. It seems that this instrument is a promising tool to investigate the variability of EI competence during the individual's lifetime. This could significantly contribute to further studies on effective leadership and the promotion of happiness, well-being, and quality of life in employees.

\section{REFERENCES}

Ackley, D. (2016). Emotional intelligence: A practical review of models, measures, and applications. Consulting Psychology Journal: Practice and Research, 68(4), 269 286. https://doi.org/10.1037/cpb0000070

Almeida, L. S. and Freire, T. (2008). Metodologia da Investigação em Psicologia e Educação (Methods of research in psychology and education) (5aㅡㄹ Edição). Psiquilíbrios.

Anastasi, A. and Urbina, S. (2000). Testagem psicológica (Psychological testing) (7th Editions). Artes Médicas.

Barbosa, F. L. S., Carvalho de Sousa, M. C., Pinto, F. Santos, A. and Moreira, R. (2016). Fatores Determinantes da Inteligência Emocional no Contexto Industrial. Qualitas Revista Eletrónica, 17(3), 86-103. http://dx.doi.org/10.18391/req.v17i3.3132

Bar-On, R. (1997). The emotional quotient inventory (EQ-i): Technical manual. Multi-Health Systems.

Bartram, D., and Hambleton, R. K. (2016). The ITC guidelines: International standards and guidelines relating to tests and testing. In F. T. L. Leong, D. Bartram, F. M. Cheung, K. F. Geisinger and D. Iliescu (Eds.), The ITC international handbook of testing and assessment (pp. 35-46). Oxford University Press.

Bartram, D., Grégoire, J., Hambleton, R., Muñiz, J. and Van de Vijver, F. (2018). ITC Guidelines for Translating and Adapting Tests (Second Edition). International Journal of Testing, 18(2), 101134. http://dx.doi.org/10.1080/15305058.2017.1398166,

Boazinha, I. (2014). Atitudes e práticas na gestão de talentos e inteligência emocional: suas interações (Attitudes and practice in talent and emotional intelligence management: interactions)[Unpublished master dissertation]. Universidade de Évora.

Brown, T. (2006). Confirmatory factor analysis for applied research. The Guilford Press.

Candeias, A. A. and Canhoto, M. (2019). Estudos de Inteligência emocional em contextos profissionais com o EIV: Metanálise dos trabalhos de adaptação à população portuguesa (Studies on emotional intelligence in professional contexts with EIV: Meta analysis of adaptation works to Portuguese population). In A. A. Candeias (Editor), Desenvolvimento ao longo da vida: Aprendizagem, Bem-estar e Inclusão (Long-life development: learning, wellbeing and inclusion) (pp. 190-203). Universidade de Évora. 
Candeias, A. A., \& Jesus, A. (2006). Inteligência social e inteligência emocional - contributos para o estudo da sua interacção em profissionais de enfermagem (Social intelligence and emotional intelligence contributions to study their interaction in nurses). In N. R. Santos, M. L. Lima, M. M. Melo, A. A. Candeias, \& A. A. Calado (Eds.), Actas do Simpósio Nacional de Investigação em Psicologia: VI Simpósio Nacional (Vol. XIX, pp.19-34). Universidade de Évora.

Dabke, D. (2016). Impact of Leader's Emotional Intelligence and Transformational Behavior on Perceived Leadership Effectiveness: A Multiple Source View. Business Perspectives and Research, 4(1), 27-40. http://dx.doi.org/10.1177/2278533715605433.

Davar, S.C. and Singh, N. (2014). Emotional Intelligence \& Job Performance in Banking \& Insurance Sector in India. The Indian Journal of Industrial Relations, 49(4), 722-733. https://www.jstor.org/stable/24546976

Eysenbach, G (2012). Correction: Improving the Quality of Web Surveys: The Checklist for Reporting Results of Internet E-Surveys (CHERRIES). Journal of Medical Internet Research, 14(1), e8. http://dx.doi.org/10.2196/jmir.2042.

Fabrigar, L. R., and Wegener, D. T. (2012). Understanding statistics. Exploratory factor analysis. Oxford University Press.

Goleman, D. (1995). Emotional Intelligence: Why It Can Matter More Than IQ for Character, Health and Lifelong Achievement. Bantam Books.

Goleman, D. (1998). Working with Emotional Intelligence. Bantam Books.

Goleman, D. (2000). An EI-based theory of performance. In D. Goleman, \& C. Cherniss (eds.), The Emotionally Intelligent Workplace: How to Select for, Measure, and Improve Emotional Intelligence in Individuals, Groups, and Organizations (pp. 27-44). Wiley.

Goleman, D. (2012). Trabalhar com inteligência emocional. Temas e Debates.

Gunkel, M., Schlaegel, C., and Taras, V. (2016). Cultural values, emotional intelligence, and conflict handling styles: A global study. Journal of World Business, 51(4), 568-585. http://dx.doi.org/10.1016/j.jwb.2016.02.001

Joseph D. L., Jin, J., Newman, D. A., and O'Boyle, E. H. (2015). Why does self-reported emotional intelligence predict job performance? A meta-analytic investigation of mixed EI. Journal of Applied Psychology, 100(2), 298-342. http://dx.doi.org/10.1037/a0037681.

Kline, R. B. (2010). Principles and practice of structural equation modeling (3rd ed.). Guilford Press.

Lee, Y. H., and Chelladurai, P. (2017). Emotional intelligence, emotional labor, coach burnout, job satisfaction, and turnover intention in sport leadership. European Sport Management Quarterly, 18(4), 393-412. https://doi.org/10.1080/16184742.2017.1406971

Maamari, B. E., and Majdalani, J. F. (2017). Emotional intelligence, leadership style and organizational climate. International Journal of Organizational Analysis, 25(2), 327-345. https://doi.org/10.1108/IJOA-04-2016-1010

Mayer, J. D., and Salovey, P. (1997). What is emotional intelligence? In P. Salovey and D. Sluyter (Eds.), Emotional development and emotional intelligence: Implications for educators (pp. 3-31). Basic Books.

Miao, C., Humphrey, R. H., and Qian, S. (2017). A meta-analysis of emotional intelligence effects on job satisfaction mediated by job resources, and a test of moderators. Personality and Individual Differences, 116, 281-288. https://doi.org/10.1016/j.paid.2017.04.031

Min, J. (2014) The Relationships Between Emotional Intelligence, Job Stress, and Quality of Life Among Tour Guides. Asia Pacific Journal of Tourism Research, 19(10), 1170-1190. https://doi.org/10.1080/10941665.2013.83945

Moreira, V. L. (2017). A Importância da Inteligência Emocional nas Organizações (Importance of emotional intelligence in organizations). Gestão e Desenvolvimento em Revista. 3(1), 84-96. http://erevista.unioeste.br/index.php/gestaoedesenvolvimento/article/view/16963

Njoroge, C. and Yazdanifard, R. (2014). The impact of social and emotional intelligence on employee motivation in a multigenerational workplace. Global Journal of Management and Business Research: Administration and Management, 14(3), 30-36. https://globaljournals.org/GJMBR_Volume14/5The-Impact-of-Social-and-Emotional-Intelligence.pdf

Nowack, K. (2004). Emotional Intelligence View 360 Facilitator's Guide. Envisia Learning.

Nowack, K. (2006). Facilitator's Guide - Emotional intelligence view 360‥ Envisia Learning.

Nowack, K. (2014). Emotional Intelligence View 360 - People Index/Research Information. Envisia Learning. Nowack, K. (2017). Sleep, emotional intelligence, and interpersonal effectiveness: Natural bedfellows. Consulting Psychology Journal: Practice and Research, 69(2), 6679. https://doi.org/10.1037/cpb0000077 
Rocha, A., Melo, M., Santos, N. R., and Candeias, A. A. (2007). Emotional Intelligence View 360 Questionnaire - Estudos psicométricos com profissionais portugueses. In A. A. Candeias, and L. Almeida (Eds) Inteligência Humana: Investigação e Aplicações (pp. 449-484). Quarteto Editora.

Salovey, P., and Mayer, J. D. (1990). Emotional Intelligence. Imagination, Cognition and Personality, 9(3), 185-211. https://doi.org/10.2190/DUGG-P24E-52WK-6CDG

Saraiva, A.P. (2007). Competências sociais e emocionais nas relações interpessoais na equipa de enfermagem do bloco [(Social and emotional skills in interpersonal relations in a nurses team) [Unpublished master dissertation]. Universidade de Évora.

Webb, K (2014). How Managers' Emotional Intelligence Impacts Employees' Satisfaction and Commitment: A Structural Equation Model. The IUP Journal of Organizational Behavior, 13(2), 7-24. http://dx.doi.org/10.2139/ssrn.2236390

$\begin{array}{ll}\text { Historial do artigo } & \\ \text { Recebido } & 03 / 2019 \\ \text { Aceite } & 01 / 2021 \\ \text { Publicado online } & 03 / 2021 \\ \text { Publicado } & 06 / 2021\end{array}$


Psychometric analysis of EIV 